\title{
Church, Apostle and Nation in Early Ireland
}

\section{Patrick Wadden*}

There is abundant evidence for the existence of the Irish nation as a concept in the early medieval period. A variety of texts, in both Latin and the vernacular, depict the people of Ireland as a community of birth, language, law, religion and, sometimes, politics. The creation and re-creation of ethnic and national identities elsewhere in late-antique and early medieval Europe, sometimes called ethnogenesis, has become a key concern of historians of this period in recent decades. This study of ethnogenesis prioritises interaction with the Roman Empire and political unity as precursors to the development of common identity among barbarian peoples. This model does not appear appropriate to explain developments in Ireland, where political fragmentation and divisions among the learned classes mitigated against the evolution of a common identity inclusive of all Irishmen. That such an identity emerged by the close of the sixth century, and gained popularity during the seventh, is discussed here in light of developments within the Irish Church, including the controversy around the Easter debate and attempts on behalf of Armagh to claim ecclesiastical primacy within Ireland. The process is elucidated through comparison with identity-formation in Anglo-Saxon England, as it can be observed primarily through the work of Bede. The result is to highlight the significance among early medieval ecclesiastical scholars of the perceived role of national apostles in establishing national churches. Ultimately rooted in their understanding of the Bible, these ideas could be deployed in both Ireland and England in support of the claims of specific churches to ecclesiastical authority.

Keywords: Ireland; national identity; ethnogenesis; Columbanus; Armagh; Muirchú; Tírechán; Liber Angeli; St. Patrick; national apostles; Bede

Writing in the late seventh century, the hagiographer Tírechán listed three petitions granted to St Patrick by an angel shortly before his death. In doing so, he repeatedly used second-person, plural pronouns in relation to the Irish (Hibernenses), and contrasted this group explicitly with 'barbarian nations` (barbaraea gentes), making his one of the most striking early medieval assertions of Irish national identity. ${ }^{1}$ Tírechán was not alone - far from it - in his belief that the

* Correspondence details: Patrick Wadden, Department of History, Belmont Abbey College, Belmont, NC 28012, USA. Email: patrickwadden@bac.edu.

1 Notes Supplementary to Tírechán, ed. and trans. L. Bieler, Patrician Texts, 164-5: Hae sunt tres petitiones Patricii, ut nobis traditae sunt Hibernensibus, rogans i. ut suscipiatur unusquisque nostrum poenitentiam agens licet in extremo uitae suae iudicii dei, ut non claudetur in inferno: haec est prima; ii. ne barbarae gentes dominentur nobis in sempiternum <: haec est secunda>; iii. ut ne superuixerit aliquis nostrum, id est Hibernensium, ante septem annos ante diem iudicii, quia septem annis ante iudicium delebuntur equore: haec est tertia. For the date, see Charles-Edwards, Early Christian Ireland, 439. 
Irish constituted a nation, or simagined community.$^{2}$ In fact, such is the abundance of textual sources from early medieval Ireland concerned with defining and exploring Irish identity that it has been said that her learned classes 'were preoccupied with this very notion ${ }^{3}{ }^{3}$

These texts, dating from as early as the seventh century, ascribe to the Irish the usual characteristics and criteria associated with ethnic and national identity in the early medieval period, including shared ancestry, language and law. ${ }^{4}$ All demonstrate the influence of biblical sources and concepts, with Old Testament Israel standing as a model for what a nation should look like. ${ }^{5}$ Perhaps the most famous of these is the national origin legend, which would attain canonical form in the twelfth century as Lebor Gabála Érenn, ,The Book of the Taking of Ireland.${ }^{6}$ This work traces the pseudo-history of the Gaels from the biblical Flood, through many travels, to Ireland. ${ }^{7}$ The final leg of this journey, which brought the Gaels from Spain to Ireland, was undertaken by the sons of Míl Espáin, who was thus presented as the apical figure to whom all the Gaels could trace their ancestry. Máel Mura Othna, the ninth-century author of a verse account of the Irish origin legend, could use the term Meic Míled, sthe children of Mík, as a name for the Irish alongside the more common 'Scots and >Gaels $\iota^{8}$ This origin legend thus provided an anchor onto which the genealogies of the various Irish dynasties could be grafted. Indeed, the genealogical system it enshrined has been described as sthe most important aspect of the whole schemer of Lebor Gabála. ${ }^{9}$ The development of this legend, and the genealogical schema it enshrines, was gradual. ${ }^{10}$ The reference to Éremón, traditionally one of Míl's two sons, in the seventh-century poem Moín oín óba noíd, >Moen the lone, since he was a childı, suggests that the process had begun already at that early date. ${ }^{11}$

2 Anderson, Imagined Communities. Following Charles-Edwards, Making the Nations, 11-12, and Reynolds, Idea of the Nation, I see no difficulty in using the terminology of nation and national identity to refer to communities in relation to the early medieval period. Some modernists, including Anderson, believe that the nation can only exist in the era of mass media, which allows historians to argue that a large portion of the population believed in its existence. The nature of the sources means that there is no way of telling how the majority of the Irish population felt about their identity in the early medieval period, but that in no way undermines the evidence for the existence of the concept of the Irish nation among the learned classes, which is the subject of the current study.

3 Ó Corráin, Nationality and Kingship, 5.

4 See, for example, Regino of Prüm, Epistula ad Hothonem, ed. Kurze, XX. See also Pohl, Telling the Difference.

5 On the importance of the biblical image of Israel as a model for medieval gentes, see Hastings, Construction of Nationhood; Smith, Chosen Peoples. For the centrality of biblical study to the learning of early medieval Ireland, see Ó Néill, Biblical Study. For Israel as a model for the Irish nation in the early medieval period, see Comerford, Ireland, 19.

6 Lebor Gabála Érenn, ed. and trans. Macalister. Macalister's editorial technique has come in for much criticism, but there is no other complete edition available. A translation of the first recension by John Carey is available in Koch and Carey (eds.), Celtic Heroic Age, 213-266. For the importance of origins legends in the early medieval period, see Reynolds, Medieval origines gentium.

7 For discussion, see Carey, Irish National Origin-Legend.

8 Máel Muru Othna, Can a mbunadas na nGaedel, ed. Best and O’Brien, Book of Leinster, 516-523 contains several examples. The translation published by Todd alongside his edition (Leabhar Breathnach, 220-271), while imperfect, is the only one currently available.

9 Carey, Irish National Origin-Legend, 10. Cf. Ó Corráin, Creating the past, 203, where the Milesian schema of Lebor Gabála is described as sthe sheet anchor of the genealogical tracts<.

10 The gradual development of the schema is discussed by Holmberg, Towards a Relative Chronology, a recent PhD. thesis, which, unfortunately, was not available to this author in time for its conclusions to be considered in depth here.

11 Corpus Genealogiarum Hiberniae, ed. O’Brien, 1, 334; Carney, Dating of Archaic Irish Verse, 46-47. See also Carney, Three Old Irish Accentual Poems, 73. 
A different origin legend asserted that it was their common language that defined individuals' membership of the Irish nation. Auraicept na nÉces, >The Scholars' Primer<, the oldest surviving grammar of a European vernacular, was first written $c .700 .{ }^{12}$ It contains an account of the origins of the Irish language that claims it had been created at the school of Fénius Farrsaid ten years after the construction of the Tower of Babel. The students who learned the language and carried it with them to Ireland became the first Irishmen, regardless of the fact that they were of diverse racial origins, for it is everyone speaking the same language that went from there to his territory and not everyone of the same races. ${ }^{13}$ This account prioritizes their common language as the defining characteristic of the Irish, and explicitly rejects the idea that they were of the same ancestral origins. With the exception of small numbers of British and Anglo-Saxon immigrants - missionaries, monks and scholars for the most part - there is very little evidence for the presence of other vernaculars in Ireland before the establishment of Scandinavian settlements during the ninth century. ${ }^{14}$ But Old Irish, the form of the Gaelic language attested between roughly 600 and 900 , was not restricted to Ireland; Gaelic speakers were present in northern Britain throughout the medieval period, as they are in Scotland today. Gaelic-speaking communities were also established in what is now Wales and Cornwall in the early medieval period, although they were not as resilient and had probably disappeared by the ninth century. There must have been considerable dialectal variation in Old Irish, considering the rural quality of Irish society and the dispersal of Gaelic speakers over such an extensive territory. Remarkably, however, surviving Old Irish texts show no evidence of this; the language of the Old Irish period is remarkably homogeneous, and the evidence for dialectal variation is tantalizingly sparse. ${ }^{15}$ It is also the case, however, that Old Irish was not simply a Schriftsprache. It was a language spoken, presumably throughout Ireland and Gaelic-speaking Britain, at least by the scholars who wrote it, and presumably also by their patrons among the political elite. ${ }^{16}$

The racial and linguistic definitions of Irish identity included the Gaels of both Ireland and Britain. A slightly different emphasis can be found in the earliest Irish legal texts. The early Irish law tracts claim to depict a legal system common to all the inhabitants of Ireland, and have been described as one of the rcentral pillars of Irish nationality in the seventh and eighth centuries $\times{ }^{17}$ Old Irish law differed from that of most other early medieval societies in that it was not promulgated by a king; rather, it was written and preserved by legal professionals who used the texts for instructional purposes. ${ }^{18}$ The most important, and possibly the oldest Old Irish law book is known to modern scholars as the Senchas Már, or >Great Tradition ${ }^{19}{ }^{19}$ The opening words of the introduction to this collection of legal tracts, and perhaps

Auraicept na nÉces, ed. Ahlqvist, 36.

13 Auraicept na nÉces, 1.4 ed. Ahlqvist, 47: is cach combérlaid do.chuaid a suidiu dochum a chríche 7 ni cach comcheniúil.

14 Russell, >What was Bests of Every Language‘, 409.

15 Russell, >What was Bests of Every Language`, 439-443; Ó Muircheartaigh, Gaelic Dialects, 146-198.

16 Charles-Edwards, Early Christian Ireland, 583; idem, Language and Society, 727-728; Russell, >What was Bests of Every Language<, 439-443.

17 Charles-Edwards, Making of Nations, 30. Cf. Ó Corráin, Nationality and Kingship, 7; MacNeill, Early Irish Laws, 74-82, 89-96; Kelly, Guide to Early Irish Law, 231-232. On the significance of written law to the identity of barbarian gentes more broadly, see Wormald, Lex scripta; idem, Leges barbarorum.

18 Kelly, Guide to Early Irish Law; Charles-Edwards, Early Irish Law.

19 On the significance of the Senchas Már, see Kelly, Guide to Early Irish Law, 242-246; Stacey, Dark Speech, $181,223$. 
its original title, are Senchas fer nÉrenn, sThe tradition of the men of Ireland, which highlights the theme of national legal unity that runs throughout the collection. ${ }^{20}$ The account of its origins contained in the Senchas Már, while certainly legendary, is probably not far from the mark in depicting the legal system it enshrines as the result of the blending of native and Christian elements. It asserts that, prior to the arrival of St Patrick, the Irish adhered to the slaw of natures, recht aicnid, which was maintained as an oral tradition. At a meeting of all the men of Ireland, convened by the king of Ireland, Lóegaire mac Néill, these laws were recited by a poet, revised by Patrick to align with Christianity, and committed to parchment for the first time. ${ }^{21}$ The legend lays great emphasis on the unity of the men of Ireland as a community linked by their adherence to a common legal system in both the present and the distant past. As a means of linking the Irish of the early medieval period with their ancestors, the Senchas Már thus served as a vvehicle of tradition` in a manner similar to the written laws of other barbarian peoples of the early medieval period. ${ }^{22}$

What makes the existence of Irish national identity distinctive within early Europe, though not unique, is the fact that the individuals believed to belong to this entity lived in a very fragmented society. Since the 1970s, students of ethnogenesis have come to emphasize the importance of political unity and interaction with the Roman empire as precursors to the development of common identities among barbarian peoples on the Continent. ${ }^{23}$ In brief, the dominant theory holds that groups of barbarians united in loose federations in order to deal with the Roman Empire. Due to Roman expectations that they would interact with barbarian gentes through the person of their individual kings, leaders were appointed to act on behalf of these confederations. Depending on the success of these 'kings`, the confederation might remain together over a long period, during which its members would adopt a common identity, generally that of the ruler, thus coalescing into a single gens. Recent work by Elva Johnston on the place of Ireland in late Antiquity proposes seeing the Irish Sea as a frontier zone comparable with those along the Rhine and elsewhere, and within which contact and communication were frequent. ${ }^{24}$ Within this context, it is possible that the process of identity formation in Ireland had begun along the same path as was the case on the other frontiers of the empire. Writing in the fourth century, Ammianus Marcellinus claimed that attacks on Roman Britain were carried out by Scotti and Atacotti, who sometimes also collaborated with Picts and Saxons. ${ }^{25}$ The Scotti and Atacotti were also associated with each other by

20 Introduction to the Senchas Már, §1, ed. and trans. Breatnach, Early Irish Law Text, 4-5.

21 The fullest account of this episode is in the early eighth-century glossing known as the pseudo-historical prologue to the Senchas Már: Carey, Edition of the Pseudo-Historical Prologue. On the centrality of the episode to Senchas Már as a whole, see Breatnach, Early Irish Law Text, 34-38; idem, Companion, 313. For commentary, see Bracken, Immortality and Capital Punishment; Ó Corráin et al., Laws of the Irish, 387; Wadden, Pseudo-Historical Origins.

22 Wormald, Leges Barbarorum, 32-33.

23 For an overview of some central ideas, see Chrysos, Empire, the gentes and the regna. The seminal work was Wolfram, Geschichte der Goten. In the last thirty years, the historiography of the topic has become vast. Some of the most important contributions to the discussion have been reprinted in Noble (ed.), From Roman Provinces to Medieval Kingdoms. For some critical approaches, see Gillett, Ethnogenesis; idem, On Barbarian Identity. The centrality of kings and kingdoms to the process of identity formation is highlighted in Goetz et al. (eds.), Regna and Gentes; Reynolds, Kingdoms and Communities; eadem, Idea of the Nation.

24 Johnston, Ireland in Late Antiquity. See also, Johnston, Literacy and Identity, 1-16 for some important points about the late-antique context of early Irish literacy.

25 Ammianus, Res Gestae, 26.4.5, cited from Freeman, Ireland and the Classical World, 95. Cf. Ammianus, Res Gestae, 20.1.1, 27.8.5, in Freeman, Ireland and the Classical World, 95-96. 
St Jerome, and it seems possible that both groups might have been inhabitants of Ireland. ${ }^{26}$ Charles-Edwards has suggested that these two groups might have represented Irish-based confederations of peoples, which he tentatively identifies with the Ulaid and the Laigin, the leading powers on Ireland's east coast in later centuries, and which might originally also have united primarily for the purpose of dealing with the Roman authorities. ${ }^{27}$ As he points out, Ammianus' statement that the Scotti and Picti had broken an arranged peace presumes a degree of formal interaction between them and the imperial authorities. The fact that these authors referred to two groups, the Scotti and the Atacotti, might reflect Roman recognition that the inhabitants of Ireland - or at least those with whom they interacted - exhibited signs of ethnic diversity. The possibility certainly exists, therefore, that interaction with Roman authorities was an important factor in the development of communal identity in Ireland, though further research into the period will be necessary before much more can be said.

The Roman historian Tacitus, writing at the end of the first century, noted that the harbours of Ireland were well known to Romans in Britain, presumably from trade. On the basis of this familiarity with Ireland, his further comment that >one of the tribal petty kings d driven out of Ireland had been given refuge by his father-in-law, Agricola, can be taken as evidence of the political disunity of Ireland at that date. ${ }^{28}$ Whatever the possible results of Roman interaction with Ireland might have been, political unity was not one of them. When sources become abundant enough for historians to build up an image of the political scene in Ireland during the seventh century, it was clear that the island was still divided into numerous kingdoms, and such political fragmentation was to remain characteristic of Ireland through the medieval period and beyond. Early medieval Ireland was home to numerous kingdoms of varying size, strength and status, from the túath, the smallest political entity, of which there were scores, through a hierarchy of overkings and on to the provincial kings, of whom there were only ever three or four competing at the highest level. ${ }^{29}$ Kingship of Ireland existed in theory, at least in some quarters, from as early as the seventh century, and the title of sking of Ireland « was occasionally accorded to the most powerful of the provincial kings. ${ }^{30}$ But the authority of these kings was unstable and ephemeral, unsupported by any institutional apparatus. The depiction of Lóegaire mac Néill in the pseudo-historical prologue to the Senchas Már convening an assembly of all the men of Ireland in his capacity as king of Ireland, while it may have been inspired by legislative assemblies that occurred in Ireland in the late seventh and early eighth centuries, is not an accurate reflection of either how the law book came into existence or the authority of the kings of Ireland in the period when it was written. ${ }^{31}$

26 Jerome, Adversus Jovinianum, 2.7, and Epistle 69.3, both cited in Freeman, Ireland and the Classical World, 99-100.

27 Charles-Edwards, Early Christian Ireland, 158-160.

28 Tacitus, Agricola, §24: unum ex regulis gentis, cited in Freeman, Ireland and the Classical World, 56-57.

29 Ó Cróinín, Ireland, 400-80o. Cf. Byrne, Irish Kings and High-Kings; Ó Corráin, Ireland Before the Normans 1-27; Ó Cróinín, Early Medieval Ireland, 41-62; Charles-Edwards, Early Christian Ireland, 8-67.

30 For references to the kingdom of Ireland and kings of Ireland, see Adomnán, Vita Columbae, I.14, 36, ed. and trans. Anderson and Anderson, 38-39, 64-67; Annals of Ulster, s. a. 703, ed. Mac Airt and Mac Niocaill, 163. For a recent reassessment of the law tracts' attitude toward a high-kingship, see Breatnach, King in the Old Irish Law Text. For a maximalist view of the kingship of Tara as an institution, see Charles-Edwards, Early Christian Ireland, 469-521.

31 Wadden, Pseudo-Historical Origins. 
It has previously been suggested that the political fragmentation of Ireland was counterbalanced by the unity of the learned classes, which has also been posited as a source for ideas about common identity. ${ }^{32}$ But learned Irishmen were not members of a homogeneous community of common outlook. ${ }^{33}$ Most famously, they were divided for most of the seventh century over the crucially important question of how to date Easter. ${ }^{34}$ This issue divided the Irish Church from the 630 s to the second decade of the eighth century. Its resolution might have precipitated the creation of the Collectio canonum Hibernensis, which was probably undertaken in the first quarter of the eighth century. ${ }^{35}$ This collection of canon law includes decrees from synods convened by both sides of the Easter debate in Ireland, the >Romans and the sHibernians', demonstrating that the divisions of the seventh century were deep enough to create separate institutional allegiances. ${ }^{36}$ Considering this evidence for diversity of opinion within learned circles in seventh-century Ireland, the possibility ought to be acknowledged that the image of the Irish as a single nation might reflect the perspective, not of the learned class as a homogeneous unit, but of a specific subsection of that group only.

This possibility is enhanced by the existence of alternative ways of depicting the identity of the inhabitants of Ireland. A small number of early texts present an image of the Irish population that is at odds with that depicted in the Milesian legend, but chimes with the image of a divided island discussed above. In the Old Irish laws, for example, the ethnonym Féni is most commonly used as a synonym for >men of Ireland.$^{37}$ Less frequently, however, the Féni are presented as just one of three population groups inhabiting the island. According to the Old Irish text known as 'The Saga of Fergus mac Léti<, in Fergus' time, sthere were three chief races in Ireland: the Féni, the Ulaid, and the Gáilni or Laigin $\triangleleft{ }^{38}$ This saga belongs to an eighth-century glossing of the law tract Cethairslicht Athgabálae, >The Four Divisions of Distraint<, one of the constituent tracts of the Senchas Már. ${ }^{39}$ Cethairsilicht Athgabálae, which probably dates from the seventh-century, itself makes reference to sthree free kindreds`, although they are not named in the original tract..$^{40}$ These are sfreer or snoble kindreds, to be distinguished from the sbase, sunfree`, or srent-paying` cenéla.$^{41}$

32 This argument is ubiquitous in much recent historiography, but is discussed specifically in relation to the origins of national identity by Ó Corráin, Nationality and Kingship, 7.

33 Johnston, Literacy and Identity, 16-26.

34 Warntjes, Victorius vs Dionysius.

35 Thurneysen, Zur irischen Kanonensammlung; Flechner, Hibernensis, 15-17. I am very grateful to Dr. Flechner for providing me with access to his forthcoming edition and study of the Hibernensis prior to publication.

36 Collectio canonum Hibernensis, 17.9, 18.2, 20.3 (`Roman< synods), 18.3, 18.6 (`Hibernian< synods), ed. Wasserschleben, 63, 66-68, 72; Flechner, Hibernesis, 30-33.

37 Bretha Crólige §57, ed. and trans. Binchy 44-5; Introduction to the Senchas Már §§1, 9, 10, ed. and trans. Breatnach, Early Irish Law Text, 4-7.

38 Binchy (ed. and trans.), Saga of Fergus mac Léti, 37, 39: batar tri primcinela in here i. feni 7 ultaig 7 gailni .i. laigin.

39 McLeod, Fergus mac Léti, 1-2; Breatnach, Companion, 338-346.

40 Corpus Iuris Hibernici, ed. Binchy, 356.6, 1897.27: trí cenéla sáera. For the identity of the tract, see Breatnach Companion, 24, 72, 286-287. For the date, see Breatnach, Early Irish Law Text.

41 For discussion, see Charles-Edwards, Early Christian Ireland, 160, 530-534; Charles-Edwards and Kelly, Bechbretha, 133-134. 
The distinction between these cenéla, a word that corresponds with Latin gentes, appears to have been based on the idea that they were of different ancestral origins. Among the earliest surviving examples of Old Irish verse, perhaps dating from as early as the first half of the seventh century, is a group of poems concerning the origins and ancestry of the Laigin that appear to present them as a distinct people. ${ }^{42}$ Énna, Labraid, luad caich, 'Énna, Labraid, praised by all, for example, traces the ancestry of the leading dynasty of the Laigin back to Labraid Loingsech, who appears to have been the apical ancestor of the people. ${ }^{43}$ Loingsech means 'voyager ' or sexiles, and another of these early poems, Moín, oín óba noíd, relates the story of how he invaded and conquered territory in Ireland from overseas. ${ }^{44}$ In the process, it explains the roots of his people's name, claiming that it was derived from the lances (laigne) that they used, and suggests that a degree of enmity existed between them and the Gaels. Another poem, Dind Ríg rüad, >Dind Ríg (is) red<, identifies Labraid's enemies as the sons of Áugaine Már, ancestor of the Uí Néill, political enemies of the Laigin in the seventh century. ${ }^{45}$ Old Irish Goídel, from which modern Gael derives, was apparently a borrowing from Old Welsh into Irish in the early seventh century. ${ }^{46}$ It might originally have been used in a more restrictive sense, before becoming a synonym of Scottus, as was the case with Féni. In other words, these poems incorporate many of the features associated with national origin legends, including an explanation of the roots of the people's name, a record of their arrival in and conquest of their territory, and the use of the image of their enemies to reinforce the unity of the group. There is good reason to think, therefore, that during the seventh century the Laigin were thought by some, and perhaps thought of themselves, as a distinct ethnic group with origins separate from those of their neighbours. ${ }^{47}$

The idea that the population of Ireland was divided into different ethnic groups, rather than united as a single people, may represent an earlier phase in the development of Irish identity, or evidence of opposition to the promulgation of ideas about Irish national identity. At the very least, these poems attest the existence of alternative viewpoints during the seventh century, prior to the Laigin and the Ulaid being subsumed within the Féni. As will be discussed below, the earliest recorded instances of Irishmen identifying themselves with an Irish nation date from the end of the sixth century. This was apparently not uncontroversial during the seventh century, but seems to have grown increasingly popular with time. In what remains of this article, it will be argued that the reasons for the increasing popularity of the idea that the Irish constituted a single gens was related to ecclesiastical concerns of the late seventh century. In pursuing this line of thought, it will prove useful to examine Irish evidence in light of that from Anglo-Saxon England, where a sense of national identity also existed in the absence of political unity.

42 Carney (Dating of Archaic Irish Verse, 43-48) argued on linguistic and stylistic grounds that the poems were earlier than this, but Ó Corráin (Irish origin legends, 57-67) argued on the basis of a reassessment of the language and on historical grounds, for the later date.

43 Corpus Genealogiarum Hiberniae, ed. O'Brien, 4-7. Dillon, Poem on the Kings of the Eóganachta, 10. The poem was extended, probably in the eighth century, by the addition of further material. Its original core is probably represented by stanzas 1-21. For the date of both portions of the text, see Carney, Three Old Irish Accentual Poems, 72-73; idem, Aspects of Archaic Irish, 430-435; idem, Dating of Early Irish Verse Texts, 177-216; idem, Dating of Archaic Irish Verse, 49-53; Ó Corráin, Irish Origin Legends, 60-67.

44 Corpus Genealogiarum Hiberniae, ed. O’Brien, 1, 334; Carney, Dating of Archaic Irish Verse, 47.

45 Corpus Genealogiarum Hiberniae, ed. O’Brien, 18; Wagner, Archaic Dind Ríg Poem, 1-2.

46 Charles-Edwards, Language and society, 723; Russell, `What was Best of Every Languager, 408.

47 Carney, Three Old Irish Accentual Poems, 73. 
Credit for forging English identity and, indeed, for settling on `English`, rather than 'Saxon< terminology to express this sense of nationality has been given to Bede. As Nicholas Brooks has commented in relation to Bede's magnus opus, the sboldness of [Bede's] conception [was] that there was a single English people (gens Anglorum) who had a single ecclesiastical history $\iota^{48}$ The idea that the English constituted a single gens was bold in the eighth century because the Anglo-Saxons lacked many of the trappings of national identity: they were divided into numerous kingdoms; some kingdoms possessed their own written laws, while others did not; ${ }^{49}$ and, as Bede reported, the peoples of the various Anglo-Saxon kingdoms did not share a common ancestry, but traced their origins to one or other of three Continental peoples, the Saxons, Angles and Jutes..$^{50}$

The 'English identity constructed by Bede transcended the political and ancestral distinctions that divided the Anglo-Saxons. ${ }^{51}$ Among the factors he identified as indicative of the nationality of the English was their common language. Bede recognized English as one of the >five languages of nations` spoken in Britain, alongside those of the British, the Gaels and the Picts, and Latin. ${ }^{52} \mathrm{He}$ could also recognize the dialectal differences that existed between $>$ Anglian and `Saxon «nglish, however, demonstrating that he acknowledged that the vernacular of the gens Anglorum was not as uniform or homogeneous as his earlier statement implied. ${ }^{53}$

As has been pointed out before, however, Bede's concept of the gens Anglorum was intimately entwined with the history of conversion. Nicholas Brooks made the insightful observation that it is only from the point at which Bede's history rreaches the Gregorian mission that he begins to talk of preaching to the English gens.${ }^{54}$ Prior to that, when Bede refers to the pagan Germanic settlers who came to Britain in the fifth and sixth centuries he uses 'Saxon` terminology borrowed from his sources, including the sixth-century British polemicist Gildas. ${ }^{55}$ Writing about the mission to convert the English, however, Bede reported that Augustine was consecrated rarchbishop of the English nation', and that he wrote to Gregory the Great from Britain to inform the pope that the English gens had received the faith. ${ }^{56}$ In other words, it was their conversion and unification as a single community of faith, a single

48 Brooks, Bede and the English, 1.

49 The kingdoms of Kent and Wessex each had their own written laws by the time Bede wrote, for the texts of which see Die Gesetze der Angelsachsen, ed. and trans. Liebermann , I, 1-14, 88-123. Bede was aware of the existence of at least those of Kent (HEGA II.5, ed. and trans. Colgrave and Mynors, 150-151).

50 Bede, HEGA, I.15, ed. and trans. Colgrave and Mynors, 50-51: Aduenerant autem de tribus Germaniae populis fortioribus, id est Saxonibus, Anglis, Iutis. Eric John has pointed out (Point of Woden, 129) that some of the terminology used in this section of the Historia Ecclesiastica differs from that used by Bede in the rest of his work, which makes it likely that he was not the original author. His decision to incorporate it into the Historia Ecclesiastica, however, is evidence that he endorsed its version of events. Brooks, Bede and the English, 11-12.

51 The topic has been much debated. See, for example, Cowdrey, Bede and the English People; Richter, Bede's Angli; Wormald, Bede, The bretwaldas; idem, Venerable Bede; Jones, Chosen Missionary People?, $101-103$.

52 Bede, HEGA, I.1, ed. and trans. Colgrave and Mynors, 16-17: quinque gentium linguis; Charles-Edwards, Making of Nations, 12-24.

53 Bede, HEGA, III.7, III.22, IV.17, ed. and trans. Colgrave and Mynors, 234-235, 282-283, 384-385; Brooks, Bede and the English, 8-9.

54 Brooks, Bede and the English, 12.

55 Bede, HEGA, I.14 (Saxonum gentem), I.15 (Saxones, Anglorum siue Saxonum gens), ed. and trans. Colgrave and Mynors, 48-4, 50-51; Gildas, De Excidio Brittanniae, 23.1 (Saxones), ed. and trans. Winterbottom, 97; Brooks, Bede and the English, 14-16. Much of what follows owes a debt to Brooks' insightful study of this topic.

56 Bede, HEGA, I.27, ed. Colgrave and Mynors, 78-79: archiepiscopus genti Anglorum ... gentem Anglorum. 
Church, that forged a single English nation from the Angles, Saxons and Jutes. For while there were many kingdoms, there was only one English Church: >That was the church to which the successive missions of Augustine and Mellitus were sent from Rome and over which the metropolitan bishops of Canterbury ... were to have authority..$^{57}$ This ecclesiastical structure, including ran episcopal government under archbishops who oversaw the church of a whole gens was later exported by Anglo-Saxon missionaries to the Continent. ${ }^{58}$

Bede's belief in the correspondence between gens and ecclesia is perhaps most apparent in the following statement regarding the missionary efforts of Gregory the Great:

Well indeed may we, the English nation (Anglorum gentem) converted by his efforts from the power of Satan to the faith of Christ, give a somewhat full account of him in our History of the Church. We can and should by rights call him our apostle (nostrum ... apostolum), for though he held the most important see in the whole world and was head of Churches which had long been converted to the true faith, yet he made our nation, till then enslaved to idols, into a Church of Christ (nostrum gentem eatenus idolis mancipatam Christi fecit ecclesiam), so that we may use the apostle's words about him >If he is not an apostle to others yet at least he is to us, for we are the seal of his apostleship in the Lord. ${ }^{59}$

As an example of self-identification with a gens, Bede's use of first-person pronouns here is reminiscent of the example of Tírechán cited above. In this passage, the coincidence of Church and nation is related to the crucial role of national apostle. It was the apostle's effort to convert the gens that created the corresponding ecclesia. The identification of Gregory as the national apostle of the English was adopted by Bede from the Whitby Life of Gregory, according to which it was Gregory's own opinion that

when all the Apostles bring their own peoples with them and each individual teacher brings his own race to present them to the Lord in the Day of Judgment, he [Gregory] will bring us - that is, the English people (gentem Anglorum) - instructed by him through God's grace. ${ }^{60}$

The image of the people's apostle judging them is derived from Christ's words to the original twelve apostles that they would sit in judgment over the twelve tribes of Israel (Matthew 19:28). It was likely also influenced by Luke's statement (10:1) that Jesus had appointed

57 Brooks, Bede and the English, 12, 14-15. Barbara Yorke (Anglo-Saxon gentes and regna, 390-391) has made the point that Bede also saw a correspondence between ecclesia and gens at a subordinate level. The various gentes that comprised the gens Anglorum were expected by Bede to have their own bishops under the authority of the archbishop of the gens Anglorum.

58 Jones, Chosen Missionary People?, 107.

59 Bede, HEGA, II.1, ed. and trans. Colgrave and Mynors, 122-123: De quo nos conuenit, quia nostrum, id est Anglorum, gentem de potestate Satanae ad fidem Christi sua industria conuertit, latiorem in nostra historia ecclesiastica facere sermonem. Quem recte nostrum appellare possumus et debemus apostolum quia, cum primum in toto orbe gereret pontificatum et conuersis iamdudum ad fidem ueritatis esset praelatus ecclesiis, nostrum gentem eatenus idolis mancipatam Christi fecit ecclesiam, ita ut apostolicum illum de eo liceat nobis proferre sermonem quia, etsi aliis non est apostolus, sed tamen nobis est; nam signaculum apostolatus eius nos sumus in Domino.

60 Vita S. Gregorii, §6, ed. and trans. Colgrave, 82-8: quando omnes apostoli, suas secum provincias ducentes / Domino in dei iudicii ostendent, atque singuli gentium doctors, nos ille, id est gentem Anglorum, eo miratius per se gratia Dei credimus edoctam adducer. 
seventy-two disciples to spread his message before him, seventy-two supposedly being the number of gentes into which mankind was divided. ${ }^{61}$ Typologically, it appears that the Whitby author was comparing the constituent gentes of the populus Christianorum, including the gens Anglorum, with the twelve tribes that together constituted Israel.

Bede's attitude toward the gens Anglorum reflects a perceived equivalence between gens and ecclesia, and highlights the significance of a national apostle in the conversion process, both in establishing an archiepiscopal Church that held authority over the converted people and at the final Judgment. This may have reflected the view of Canterbury and, ultimately, Rome that there should be a single, unified Church, under Canterbury's leadership, as Wormald argued..$^{62}$ Certainly it endorsed Canterbury's status. Bede's influence and impact in forging the concept of the English gens was unparalleled, and it is likely due to him that the English are 'English rather than Saxons. ${ }^{63}$ Bede's concept of the gens Anglorum and its relationship to the ecclesia Anglorum was shaped by his reading of Scripture, but also by Gregory the Great, who was not only one of the heroes of the Historia Ecclesiastica, but also one of the great influences on its author's mode of thought, and from whom he borrowed both ideas and terminology.

On one level, Christianity was a universalizing religion. ${ }^{64}$ St Paul's epistle to the Colossians (3:11) emphatically states that among Christians sthere is neither Greek nor Jew, circumcised or uncircumcised, barbarian, Scythian, slave or free, but Christ is all and is in allk. In late Antiquity, as Christianity spread, exegetes struggled with how to define this new community. On the one hand, Christians were the new Israel, the chosen people of the new dispensation. On the other hand, they lacked the trappings of nationality - common ancestry, language and laws - that had defined the Hebrews as a community. Christians could therefore identify with two communities. On the one hand, they were members of the universal Christian people (populous Dei, populus Christianus).

On the other hand, Christians could identify with the gentes, who were called to believe in Christ and were destined to replace Israel as a people of God in the New Testament ... This peculiar combination of claims to election and universalism was expressed through the notion of the Christians [as] a single people of God, but one which consisted of believers from many different peoples, a populus ex (diversis) gentibus. ${ }^{65}$

Gregory the Great was an influential proponent of these ideas about >diversity within unity ${ }^{66}$ This outlook is apparent in Gregory's correspondence with the monk Augustine, chosen to lead the mission to the Anglo-Saxons, as recorded by Bede. From Britain, Augustine wrote to the pope a series of questions, the second of which enquired whether »Even though the faith

61 The notion that there were seventy-two languages and seventy-two gentes derived from the seventy-two descendants of Noah is ultimately based on Genesis 10, the Septuagint version of which lists the seventy-two. This became a common topos in early medieval scholarship. See, for example, Isidore, Etymologiae, IX.2.2, ed. Lindsay. For discussion, see Borst, Der Turmbau von Babel.

62 Wormald, Bede, The bretwaldas, 125-129; idem, Bede and the Church, 18.

63 On Bede's significance in shaping the concept of English identity for later generations, see Brooks, Bede and the English, 21-22; Foot, Making of Angelcynn.

64 For what follows, see especially Heydemann, People(s) of God?; eadem, Biblical Israel.

65 Heydemann, People(s) of God?, 30-31.

66 Meyvaert, Diversity within Unity; Markus, Gregory the Great, 72-80. Charles-Edwards, Perceptions of Pagan and Christian, 271-276. 
is one are there varying customs in the churches? And is there one form of mass in the Holy Roman Church and another in the Gaulish churches? ${ }^{67}$ Gregory's response was that Augustine should select whichever customs of the Roman and Gaulish churches he found most pleasing to God, and teach them to the >Church of the English ${ }^{68}{ }^{68}$ As Heydemann pointed out, the word ecclesia rcould either encompass the Christian world in its entirety ... or be applied in quite specific terms to a concrete historical embodiment of such a Christian peopler. ${ }^{69} \mathrm{Just}$ as the populus Dei consisted of numerous gentes, so in Gregory's view the universal Church, ecclesia, was envisioned as comprising numerous ecclesiae corresponding to those gentes.

Gregory apparently conceived of the mission he sent to the Anglo-Saxons as directed toward the conversion of a gens into an ecclesia. In his own writings, he consistently presented the mission as being directed towards the gens Anglorum, the English nation', as a single unit. ${ }^{70}$ Gregory's understanding of the mission's goal was shaped by Christ's instruction to his followers that they rteach all nations (Matt 28:19: docete omnes gentes), which emphasized the place of gentes in the conversion process. ${ }^{71} \mathrm{~A}$ century or more later, this idea also inspired the Anglo-Saxon missionaries active on the Continent, as Miriam Adan Jones pointed out, citing the letter of Bishop Torthelm of Leicester in which he exhorted the missionary Boniface to smake haste ... to gather [the Saxons] together and dedicate them to Christ as a new people.$^{72}$ In this letter, as in Gregory's writing, ' [i]t is taken for granted that a people would have a common faith, and that conversion means collective conversion. ${ }^{73}$ What exactly constituted the gens Anglorum in the late sixth and early seventh centuries is very uncertain - there is certainly no evidence that the Anglo-Saxon inhabitants of Britain had begun to think of themselves as members of a single people at this date - but the influence of Gregory's words and thoughts on Bede more than a century later were of profound significance. See, for instance, Bede's statement above that Gregory was the head of many Churches, and that, through his efforts, the English nation had become another one among their number.

Gregory's attitude toward gentes and ecclesiae finds an echo in the letters of his contemporary and correspondent, the Irishman Columbanus. In a letter addressed to a Frankish synod in 603, Columbanus asserted swe are all joint members of one body, whether Gauls or Britons or Irish, or whatever our gens may be.$^{74}$ Columbanus' letter to the Frankish synod,

67 Bede, HEGA I.27, ed. and trans. Colgrave and Mynors, 80-81: Cum una sit fides, sunt ecclesiarum diuersae consuetudines, et altera consuetudo missarum in sancta Romana ecclesia atque altera in Galliarum tenetur?

68 Bede, HEGA I.27, ed. and trans. Colgrave and Mynors, 80-83: Anglorum ecclesia. Gregory referred again to the Anglorum ecclesia in another letter to Augustine recorded by Bede (HEGA I.29, ed. and trans. Colgrave and Mynors, 104-105).

69 Heydemann, People(s) of God?, 30.

70 See the letters to Mellitus (Bede, HEGA, I.30, ed. and trans. Colgrave and Mynors, 106-107: Anglorum ... gens ipsa), and King Æthelberht (Bede, HEGA, I.32, ed. and trans Colgrave and Mynors, 110-111: gente Anglorum). For further instances in letters not recorded by Bede, see Brooks, Bede and the English, 13.

71 See Pohl's comment (Introduction, 18) that the conversion of the barbarian peoples "tended to focus on peoples«.

72 Epistola 47, ed. Tangl, 296, ll. 10-11: Festinet ... uti novum christo populum coacervare et dedicare.

73 Jones, Chosen Missionary People?, 101-102.

74 Columbanus, Epistula II.9, ed. and trans. Walker, 22-23: unius enim sumus corporis commembra, sive Galli, sive Britanni, sive Iberi, sive quaeque gentes. I have altered Walker's translation of Galli, which he rendered 'Franksく. Cf. Columbanus's plea in the same letter (II.6, ed. and trans. Walker, 16-17): Capiat nos simul oro Gallia, quos capiet regnum caelorum, si boni simus meriti; unum enim regnum habemus promissum et unam spem vocationis in Christo. 
like an earlier one to Gregory, was largely concerned with the thorny issue of Easter. In his letters to the popes, while vehemently asserting his and his compatriots' catholicity, orthodoxy and loyalty to Rome, Columbanus also defended their right to use a method of dating Easter distinct from that then favoured in Rome on the basis that national Churches ought to reflect the diversity of those nations they represented. ${ }^{75}$ In one letter, Columbanus cited in support of this proposition a canon of the Council of Constantinople that schurches of God planted in pagan nations should live by their own laws, as they had been instructed by their fathers.$^{76}$ Columbanus, like Gregory, believed that diversity could exist within the unity of the faith, and linked that diversity with the fact that Churches reflected the distinct identities of the nations among whom they had been established.

A key plank of Columbanus' argument was that distinct practices did not connote heresy or disloyalty. He therefore took pains to assert Irish loyalty to Rome as sthe head of the churches of the world`, whose fame had spread throughout the world, which was a cause of great joy rto almost all nations, including the Irish. ${ }^{77}$ In a letter to Pope Boniface IV, Columbanus stated that the Irish were particularly closely connected to Rome because Christianity had been brought to them rby you first, who are the successors of the holy apostles<. ${ }^{78}$ This has been read as evidence that he was aware of Prosper of Aquitaine's report, in his Chronicon, that Pope Celestine I had ordained Palladius and sent him ras their first bishop, to the Irish (Scotti) believing in Christ in $431 .^{79}$ In his Contra Collatorem, Prosper referred to this event again, this time in reference to converting Ireland to Christianity, and again stated that Pope Celestine I had ordained Palladius sbishop for the Irish` (Scotis episcopo). ${ }^{80}$ If Columbanus was recalling the Palladian mission in this letter, then, like Bede, he would have been aware that the Christian community to which he belonged was one that had been defined, from its inception, in national terms. Columbanus used several terms to refer to the Irish, one of which was that used by Prosper in relation to Palladius' mission, Scotti. ${ }^{81}$

Columbanus has been called the first Irishman on the basis of his being the first identifiable individual to assert a sense of Irish identity. ${ }^{82}$ But Columbanus' Irishness was situational. ${ }^{83}$ He referred to it only rarely in his writings, and there is good reason to believe that he did

75 Columbanus, Epistula V.3, ed. Walker, 38-39: Nos enim sanctorum Petri et Pauli et omnium discipulorum divinum canonem spiritu sancto scribentium discipuli sumus, toti Iberi, ultimi habitores mundi, nihil extra evangelicam et apostolicam doctrinam recipientes; nullus hereticus, nullus Iudaeus, nullus schismaticus fuit; sed fides catholica, sicut a vobis primum, sanctorum videlicet apostolorum successoribus, tradita est, inconcussa tenetur.

76 Columbanus, Epistula III.3, ed. Walker, 24-25: ecclesias Dei in barbaris gentibus constitutas suis viverer legibus, sicut edoctas a patribus. The reference is to 1 Constantinople (A.D. 381), c. 2.

77 Columbanus, Epistula V.11, ed. Walker, 48-49: orbis terrarum caput ... ecclesiarum; omnium prope gentium.

78 Columbanus, Epistula V.3, ed. Walker, 38-39: a vobis primum, sanctorum videlicet apostolorum successoribus.

79 Prosper of Aquitaine, Epitoma Chronicon, s.a. 431, ed. Mommsen, I.473: Ad Scottos in Christo credentes ordinatus a papa Caelestino Palladius primus episcopus mittitur. Charles-Edwards, Early Christian Ireland, 182-183, 239240,375 .

80 Prosper of Aquitaine, Liber Contra Collatorem, c.21 (58), ed. Migne, PL 51:271. On Palladius' mission, see Charles-Edwards, Palladius, Prosper, and Leo the Great; Etchingham, Conversion in Ireland, 183-186.

81 For the Irish as Hibernicis and Iber see Columbanus, Epistulae II.4, II.8 and V.2 ed. Walker, 6, 22, 38. See note 85 below for Columbanus' reference to himself as a Scottus.

82 Bracken, Introduction, 5. See also Bracken, Rome and the Isles, 78: "[Columbanus'] letters are important not least because they are the earliest expressions of Irish identity in existence."

83 Geary, Ethnic Identity. 
so on these occasions for specific purposes. Charles-Edwards has argued that, in the context of the Three Chapters controversy, it was convenient for Columbanus to play the part of an outsider in his letter to Pope Boniface from the royal court of the Lombard king. ${ }^{84}$ Columbanus was attempting to restore unity among the Catholics of Italy, and found his identity as an outsider distinctly useful in doing so. A ^dull Irish pilgrim « was clearly an outsider without his own horse in the complex race of intertwining loyalties that constituted the controversy. ${ }^{85}$ As an Irishman, he was firm in his allegiance to Rome, but only to the Rome of Saints Peter and Paul; as he pointed out, the Irish had never been part of the Roman Empire, so he had no allegiance to Constantinople: 'For we, as I have said before, are bound to St Peter's chair; for though Rome be great and famous, among us it is only on that chair that her greatness and her fame depend. ${ }^{86}$ At times, Columbanus presents his Irishness in geographical terms, referring, for example, to Ireland's peripheral location at the ends of the earth. ${ }^{87} \mathrm{Da}$ mian Bracken has argued that this conceptualization of Irishness seems to have been shaped by a complex contemporary debate concerning orthodoxy, which must be interpreted in the context of earlier literature that considers the significance of establishing Christianity in barbarian lands.$^{88}$ Those who opposed the line taken by Columbanus in relation to Easter described Ireland's location by using rhetoric that connected geographical isolation with doctrinal waywardness ${ }^{89}$ Columbanus' emphasis on Ireland's geographical distance from Rome was presented in the context of his assertions of orthodoxy as a counter to these claims.

Columbanus might have been all the more aware of his Irishness from having traveled so widely on the Continent and having encountered its cultural diversity. But his expressions of his Irish identity were part of broader theological and ecclesiastical debates. At times, during the contentious conflicts that ravaged the Church in Italy, it suited him to be an outsider. At other times, when asserting the orthodoxy and catholicity of adherents to the controversial 'Celtic Easter, it suited him to flatter the papacy by reminding the pope of his predecessor's achievement in establishing the faith in Ireland, which had remained beyond the reach even of the empire, and which had continued, since its foundation, to be orthodox and catholic. And sometimes it suited him to defend the method of dating Easter he and his compatriots used by asserting that the Irish Church, like those established among other gentes, ought to have its own national character, a view shared by Gregory the Great and others.

While Columbanus cited the canon from the Council of Constantinople that Churches established among the gentes should follow their own laws ras instructed by their fathers<, and possibly alluded to Palladius' mission to Ireland, he did not go so far as to identify Palladius, or anybody else, as the sfather of the Irish Church. Within a generation of Columbanus' death, however, such a figure was beginning to emerge. Cummian, in his letter concerning

84 For what follows, see Charles-Edwards, Early Christian Ireland, 372-375.

85 Columbanus, Epistula V.14 ed. Walker, 52-53: peregrinum ... Scotum hebetem.

86 Columbanus, Epistula V.11, ed. Walker, 48-49: Nos enim, ut ante dixi, devincti sumus cathedrae sancti Petri; licet enim Roma magna est et vulgata, per istam cathedram tantum apud nos est magna et clara.

87 Columbanus, Epistula V.3, V.11 ed. Walker, 38-39, 48-49.

88 Bracken, Rome and the Isles, 78.

89 Bracken, Rome and the Isles, 90. See, for example, Bishop Wilfrid's speech at Whitby, as reported by Bede (HEGA, III.25, ed. and trans. Colgrave and Mynors, 300-301), where he refers to those who adhered to what he considered the heresy of the >Celtic Easter, including the Irish, British and Picts, as inhabitants of »two remotest islands of the Ocean«, duabus ultimis Oceani insulis. 
the Easter controversy written in $632-633$, referred to St Patrick as papa noster.${ }^{90}$ Cummian himself was associated with the churches of southern Ireland, possibly Clonfert, and one of the recipients of his letter, Ségéne, was the abbot of Iona, the island monastery off the coast of what is now Scotland. That he could use this honorific title, without further explanation, suggests that Patrick was held in high regard over a broad territory already at that date. ${ }^{91}$

Grander, and more detailed claims regarding Patrick's status were made in the HibernoLatin, abecedarian poem Audite omnes amantes..$^{92}$ Audite omnes, which survives in the Antiphonary of Bangor, was written at the end of the seventh century, and while the exact date of composition is debated, most would see it as a product of the early to mid-seventh century. ${ }^{93}$ As Andrew Orchard has shown, its author demonstrates great skill in his use of biblical and other sources in his presentation of Patrick..$^{94}$ Here St. Patrick, in whose honour the hymn was composed is requal to the apostles` (line 4) and will sreign with the apostles over Israek (92); reflecting a theme of Patrick's own writing, the poem claims that he received his apostolate directly from God $(11,13)$; he is compared with St Peter, upon whom the Church is built (10); and with St Paul, like whom he was sent by God as an apostle to gentes (27). Crucially, there is no room here for other missionaries - Ireland was converted by Patrick and Patrick alone. Jean-Michel Picard has recently discussed the significance of the development of the image of Patrick's apostolicity in relation to a belief current in late Antiquity and the early medieval period that , [t] he only churches who could claim to be orthodox were those who could prove a regular succession of bishops beginning with a disciple of the apostles or "apostolic men", that is men who were companions of the apostles.${ }^{95}$ By identifying Patrick as the apostle of the Irish, the poem is, like Columbanus, arguing for the orthodoxy of the Irish Church in the midst of the Easter controversy.

Patrick never claimed to have converted all the people of Ireland, as reported by Audite omnes, but in other ways the poem does reflect some of its subject's own words as preserved in his Confessio and Epistola ad milites Corotici. ${ }^{96}$ Charles-Edwards has recently argued that Patrick used the term gentes to refer to pagans, either as individuals or collectives. ${ }^{97}$ So, while the crew of the ship on which Patrick returned to Britain after his enslavement in Ireland were gentes, the pagan Irish among whom he worked were collectively a gens, a term he also used with reference to the Franks. ${ }^{98}$ Similar language is used in Audite omnes Patrick was the rock upon which the Irish Church was built because he had been appointed

90 Cummian, De Controversi Paschali, 11 208-209, ed. and trans. Walsh and Ó Cróinín, 84-85.

91 For the early development of Patrick's cult, see Sharpe, St. Patrick and the See of Armagh; Doherty, Cult of St. Patrick.

92 Audite omnes amantes, ed. and trans. Orchard, 166-173

93 Orchard, Audite omnes, 162-163; O’Loughlin, Discovering Saint Patrick, 103-4; Doherty, Cult of St Patrick, 88-92.

94 Orchard, Audite omnes, 53-65.

95 Picard, Vir apostolicus, quoted at 428.

96 Both are edited and translated in Bieler, Libri Epistolarum. For Patrick's concept of his own mission, see O'Loughlin, Discovering Saint Patrick, 58-59, 63-95; idem, Patrick on the Margins, 52-58; Charles-Edwards, Early Christian Ireland, 214-216. The literature on Patrick is far too abundant to be listed here, but for a recent, relatively brief, overview of his mission, see Etchingham, Conversion in Ireland, 187-196.

97 Charles-Edwards, Perceptions of Pagan and Christian, 263-265.

98 Patrick, Confessio, 18, ed. and trans. Bieler, 67-68; Patrick, Epistola, 10, 14, ed. and trans. Bieler, 96-97, 98-99. 
by God apostle of the pagan Irish, Hibernas gentes. ${ }^{99}$ Audite omnes was a source utilized by other Patrician hagiographers later in the seventh century. It represents the first stage in the development of the cult of Patrick that transformed him from the zealous yet occasionally human and vulnerable bishop of the fifth century into the miracle-working, vanquisher of druids he would soon become.

The next stage in Patrick's transformation occurred as part of a concerted campaign to elevate Armagh to primatial status within the Irish Church toward the end of the seventh century. Perhaps inspired by the establishment of Canterbury as the head of the Church in Britain, and the use of the archiepiscopal title by its metropolitan, the seventh century witnessed competition between rival foundations in Ireland for similar recognition. ${ }^{100}$ The surviving records of this debate can be read in hagiographical texts from the period. For example, the earliest candidate for primacy within Ireland was Kildare, the church of St Brigit. Kildare's ambitions were asserted by Cogitosus, in whose Life of the founding saint he claimed for Kildare the status of shead of almost all the Irish churches with supremacy over all the monasteries of the Irish, and its parochia extends over the whole land of Ireland, from sea to sear, and asserted that it was home to rthe archbishop of the bishops of the men of Ireland ${ }^{101}$ The term parochia (otherwise paruchia), referred to the territorial extent of episcopal authority. ${ }^{102}$ Kildare's claim, therefore, was to archiepiscopal authority over the entire island.

Kildare's claims were ultimately unsuccessful, as Armagh eclipsed all its rivals in the race for primatial status. This was achieved in part through an astute political alliance with the most powerful dynasties in Ireland, the Uí Néill, but also through the assiduous promotion of the cult of St Patrick in a dossier of seventh-century hagiographical texts. ${ }^{103}$ This dossier comprised the Liber Angeli, Muirchú's Vita Sancti Patricii Confesoris, and Tírechán's Collectanea, complex, multi-valent texts that tell us a lot about Armagh's politics, about theology and scholarship, and about a host of other things, and which should not be reduced to any single interpretation. ${ }^{104}$

Armagh's claims rested squarely on its association with Patrick, whose cult therefore needed careful cultivation. Its case is laid out relatively clearly in the Liber Angeli, probably the earliest of the three texts. Here it is implied that Patrick was responsible for the conversion of the Irish (conuersionem Hibernensium), and would therefore judge all the Irish (omnes Hibernenses) at the final Judgment; that he loved Armagh, his primary foundation, more than any of the other lands or churches of Ireland; and that, therefore, God had given all the peoples of the Irish (uniuersas Scotorum gentes) as a paruchia to Patrick and Armagh, so that Armagh was "the see of the archbishop of the Irish, that is, (the see) of Patrick (cathedram

99 Audite omnes amantes, 1. 18, ed. and trans. Orchard, 168-169.

100 Charles-Edwards, Early Christian Ireland, 416-440; De Paor, Aggrandisement of Armagh, $100-110$.

101 Cogitosus, Vita S. Brigidae, AAAS Feb. 1, §2, col. 135B: caput pene omnium Hibernensium ecclesiarum et culmen praecellens omnia monasteria Scottorum cuius parochia, per totam Hibernensem terra diffusa, a mare usque ad mare extensa est ... archiepiscopus Hibernensium episcoporum; translation adapted from Connolly and Picard, Cogitosus's Life of St Brigit, §§4, 6 (11-12).

102 Etchingham, Implications of paruchia; idem, Church Organisation, 105-125.

103 De Paor, Aggrandisement of Armagh; Binchy, Patrick and his Biographers.

104 O'Loughlin, Muirchú's Theology, 124-125, makes this point well. 
archiepiscopi Hibernensium, id est Patricii). ${ }^{105}$ In other words, what is being claimed here is that the archbishop of Armagh, as the successor of St Patrick, also had a right to ecclesiastical authority over the entire island of Ireland and all of its inhabitants. The synonymous use of $S \cot (t) i$ and Hibernenses is common to the three documents that make up the Armagh dossier, and is reflective of Patrick's own vocabulary. For Patrick, the Irish were Scotti or Hiberionaci. ${ }^{106}$ It was only natural that authors writing about the foundation of the Irish Church should draw on the language used by those involved in that process, as Bede had done.

These ideas were reasserted by Muirchú and Tírechán, who constructed Patrick's career around them and the evidence of Patrick's own writings. They each fleshed out the story of Patrick's missionary career in different, though equally unhistorical ways. Tírechán's concerns were often political, and his record of Patrick's travels around Ireland can be read as a commentary on the political alliances of Armagh in the late seventh century. ${ }^{107}$ In relation to Armagh's status, he followed the path signposted by the Liber Angeli. God gave the whole island and its inhabitants to Patrick, who single-handedly converted them through preaching and baptism, as a result of which Patrick's heirs in Armagh were entitled to authority over ralmost the whole island ${ }^{108}$ Tírechán's record of the petitions granted to Patrick by an angel, referred to at the start of this article, outlined to Irishmen of Tírechán's own day and future generations what the benefits of this arrangement were for them. Patrick requested that any Irishman who did penance, even on his last day, would be accepted into heaven, and that the Irish would not be ruled over by barbarae gentes. ${ }^{109}$ In other words, Patrick would protect the Irish nation in this life and the next.

Muirchú added further important elements to this theory. Again, as was to become standard, he depicted Patrick as having converted Ireland single-handedly. Muirchú's theology of conversion is detailed and subtle, however, as discussed by Thomas O'Loughlin, and is at the heart of his thinking about the identity of the Irish nation. ${ }^{110} \mathrm{He}$ associated conversion closely with both baptism and Easter, and, at the first Easter to be celebrated in Ireland, it was the Irish nation as a whole that was baptized and converted - having been prepared for the coming of Patrick as the Hebrews had been prepared for the coming of Christ. ${ }^{111}$ Muirchú completes his overhaul of Patrick's story and the elevation of his cult - and with it the status of Armagh - by borrowing and developing the idea of Patrick's apostolicity from Audite omnes. Like Tírechán, Muirchú includes the story of Patrick being granted petitions by an angel shortly before his death, though in his telling the petitions are a little different. The first, that Patrick's 'preeminence shall be in Armagh«, was concerned to ensure Armagh's status as Pat-

105 Liber Angeli, 4, 7, 8, 23, 28, ed. and trans. Bieler, 184-185, 188-189.

106 Patrick, Confessio, §§23, 41, 42, ed. Bieler, Libri Epistolarum, I:71, 81; Patrick Epistola ad Milites Corotici, §§2, 12, 16, ed. Bieler, Libri Epistolarum, I:2, 12, 16.

107 Charles-Edwards, Early Christian Ireland, 8-67; Swift, Tírechán’s Motives.

108 Tírechán, Collectanea, ed. and trans. Bieler, 138-139.

109 See footnote 1 , above. Tírechán's reference to the barbarae gentes was probably related to the Northumbrian attack on Brega in 684. Though the episode was not characteristic of Anglo-Irish relations during the seventh century, it gained a certain notoriety in Ireland. References to the threat posed by English invaders appear in a host of late seventh- and early eighth-century texts, some of which seem to have been intended to bolster the unity of the men of Ireland. For discussion, see Wadden, First English invasion.

110 O'Loughlin, Muirchú's theology of conversion, 127-133; idem, Discovering Saint Patrick, 112-130. See also, Flanagan, Strategies of Distinction, 107.

111 O’Loughlin, Muirchú's Theology of Conversion, 131-133. 
rick's primary foundation in the absence of his bodily relics. ${ }^{112}$ The fourth petition granted to Patrick, as reported by Muirchú, is of greater interest to the current debate In this account, the angel says to Patrick sthat all the Irish on the day of judgment shall be judged by you (as is said to the apostles: "And you shall sit and judge the twelve tribes of Israel«), so that you may judge those whose apostle you have been ${ }^{113}$ Here we see a striking parallel with the claim in the Whitby Life of Gregory, written perhaps a generation later, regarding the relationship between apostles and gentes and founded on the author's reading of Matthew 19:28.

The author of the Liber Amgeli, Tírechán and Muirchú all take it for granted that an Irish nation existed. In this they were influenced by their reading of Scripture, but also of Prosper of Aquitaine, Patrick and doubtless other sources. In terms of what it meant to them that the Irish were a single gens, it is noteworthy that all three referred in their texts to the Irish language, and Tírechán and Muirchú describe the Ireland of Patrick's time as politically united under Armagh's allies, the Uí Néill rulers of Tara. ${ }^{114}$ But what mattered most for them was that the Irish were Patrick's people. He had converted them, he had established their Church, and he awaited them at the final Judgment. They were also to be united under the authority of his church at Armagh, just as the English were to be united under the church established by Gregory's authority at Canterbury. The unity of Patrick's people and Patrick's Church was conceivable in the late seventh century in the way it hadn't been for two generations. References in these Patrician texts to Armagh's possession of Roman relics, including relics of SS Peter, Paul, Lawrence and Stephen, and the assertion that legal cases that could not be settled in Armagh should be sent for adjudication to Rome suggest that Armagh had converted to the >Roman< Easter (shortly) before these texts were written. ${ }^{115}$ The way was now open for the (re-)unification of the Irish Church, and Armagh was attentive to the possibilities this presented.

The rapid spread of Patrick's cult, propelled by Armagh, promoted also the concept of Irish national identity. Recent research has also suggested that Armagh and its allies might have had a hand in providing the Irish with the trappings of national identity, a process which would have underscored its argument regarding Irish ecclesiastical unity. For example, Liam Breatnach has recently argued that the Senchas Már was the product of Armagh. ${ }^{116}$ For nearly a century, the prevailing opinion regarding the origins of the Senchas Már was that it had been compiled in the eighth century, perhaps in response to the compilation of Collectio canonum Hibernenses, from individual tracts composed over several previous

112 Muirchú, Vita Sancti Patricii Confessoris II.6.1 ed. Bieler, 116-117: in Ardd Machæ fiat ordination. On Patrick's burial and the location of his bodily relics, see Muirchú, Vita Sancti Patricii Confessoris II.9-14 ed. Bieler, 118123.

113 Muirchú, Vita Sancti Patricii Confessoris II.6.3, ed. Bieler, 116-117: ut Hibernenses omnes in die iudicii a te iudicentur (sicut dicitur ad apostolos 'Et uos sedentes iudicabitis duodecim tribu[bu]s Israel'), ut eos quibus apostolus fuisti iudices. Muirchú had earlier (I.28, ed. and trans. Bieler, 100-101) referred to Patrick as an rapostolic man<.

114 For references to the Irish language, see Liber Angeli, 8, ed. and trans. Bieler, 184-185; Tírechán, Collectanea 4, 13, ed. and trans. Bieler, 126-127, 134-135; Muirchú, Vita Sancti Patricii Confessoris I.10 ed. and trans. Bieler, 76-77.

115 Liber Angeli, 19, 28-29, ed and trans. Bieler, 167-167, 188-191; Tírechán, Collecanea, II.3.5 and 48.3, ed. and trans. Bieler, 122-123, 160-161; Charles-Edwards, Early Christian Ireland, 438-440.

116 Breatnach, Early Irish Law Text. 
decades at a number of different centres. ${ }^{117}$ Breatnach's alternative view sees the Senchas Már as a unitary whole, ran integrated coherent text, rather than a loose assemblage of individual tracts or groups of tracts<, written in its entirety, between 660 and 680 at Armagh. ${ }^{118}$ Breatnach's argument is based on what he has identified as a parallel focus on the unity and integrity of the island of Ireland in both the Latin hagiographical products of the Armagh scriptorium and the Old Irish text of the Senchas Már. Specifically, he cites the importance of Patrick's role in the story concerning the origin of written law in Ireland that is contained within the law tracts themselves, and the repetition of the phrases sthe island of Ireland and this island, phrases not commonly found in other early Irish sources, in either Latin or vernacular texts. ${ }^{119}$ The case can not be closed on the Senchas Már, however; as noted above, Patrick's special status was recognised in texts not associated with Armagh, including Cummian's Paschal letter and Audite omnes amantes. Nonetheless, Ireland's oldest and most important law book, in which the legal unity and homogeneity of the men of Ireland was proclaimed, certainly shared some concerns with Patrician hagiography, and was perhaps part of Armagh's literary arsenal.

Peadar Ó Muircheartaigh has also suggested a possible link between the homogeneity of Old Irish and the influence of Armagh. Where others had suggested a link between the political dominance of the Uí Néill and the emergence of a single dialect as a standard language, ${ }^{120}$ or suggested that the role of the native learned classes was of great significance in maintaining that standard because of their mobility, ${ }^{121} \mathrm{O}$ Muircheartaigh argued from a socio-linguistic perspective in favor of the creation and promotion of the standard language by a network of churches linked to Armagh. ${ }^{122}$ Charles-Edwards had previously suggested that the origin legend of Old Irish - that it was created and taught to students in a school - might have been reflective of the reality of many scholars' interaction with the standard form of the language. ${ }^{123}$ Perhaps the network of churches associated with Armagh provided the classrooms. Armagh, Ó Muircheartaigh suggests, was the sregulator of the standard, which was likely based on the dialect of Ireland's northeast, whence Armagh might have adopted it at the same time it adopted the cult of St Patrick from much the same region. ${ }^{124}$ Ó Muircheartaigh's argument is based on certain key premises that would not go unchalleng-

117 Thurneysen, Aus dem irischen Recht Iv, 186-187; Thurneysen, Celtic law, 56; Binchy, Linguistic and Legal Archaisms, 112-113; idem, Linguistic and Historical Value, 86; Ó Corráin et al., Laws of the Irish, 385; Kelly, Guide, 245; Charles-Edwards, Early Mediaeval Gaelic Lawyer, 6; idem, Early Irish Law, 342-350; Stacey, Dark Speech, 178-182.

118 Breatnach, Early Irish Law Text, 19-42, quoted at 34. For the evolution of some of these ideas, see also Breatnach, Companion, 310-314; idem, King in the Old Irish Law Text, 125-127.

119 Breatnach, Early Irish Law Text, 37-40.

120 Charles-Edwards, Early Christian Ireland, 583; idem, Nations and Kingdoms, 34; Johnston, Literacy and Identity, 22.

121 Thurneysen, Grammar of Old Irish, 12; Mac Cana, Cult of the Sacred Centre, 277-278; Charles-Edwards, Early Christian Ireland, 583; Breatnach, On Satire, 34. For a criticism of this argument, see Johnston, Literacy and Identity, 22-23, where it is pointed out that not all learned communities shared the same interests.

122 Ó Muircheartaigh, Gaelic Dialects, 146-198. On Armagh's significance as an early center of learning, see also Ó Néill, Biblical Study, 13-15.

123 Charles-Edwards, Making of nations, 32.

124 Ó Muircheartaigh, Gaelic dialects, 217-236. On the significance of the northeast in the development of the earliest examples of vernacular Irish literature, see Mac Cana, Mongán mac Fiachna, 102-112; Ní Dhonnchadha Beginnings of Irish vernacular, 547. 
ed by certain historians. His assertion that the suse of Old Irish as both a literary and legal medium is closely if not exclusively associated with an ecclesiastical context $<,{ }^{125}$ would not satisfy those who believe there was a degree of literacy among non-ecclesiastical learned classes, for example. ${ }^{126}$ That position has lost favor in recent decades, however, and Ó Muircheartaigh's argument is not out of line with the more general trend toward recognizing the pervasive influence of Christian scholars in the composition of vernacular texts of all genres. ${ }^{127}$

Ó Muircheartaigh's argument regarding the origins of standard Old Irish highlights another significant aspect of Armagh's history: even in the seventh century, it stood at the head of a network of monastic houses that was spread across a great swathe of Ireland. Tírechán's Collectanea recounting of Patrick's travels around Ireland establishing churches also has the purpose of demonstrating to its readers which ones belonged to this network. ${ }^{128}$ These included churches throughout the northern half of the country, not restricted by kingdom or province. That Armagh's reach extended even further is evident from the so-called stestament of Áed of Sletty<, according to which the church of Sletty in the province of Leinster in southeast Ireland formally recognized Armagh's authority shortly before $688 .{ }^{129} \mathrm{In}$ other words, Armagh's network extended over a vast territory, far more than was governed by any single king. Furthermore, Armagh's network consisted of centers of learning - or at least centers of literacy - through which the ideas espoused in the various texts linked with Armagh could have found a broad audience. Evidence of this can be found in the work of Tírechán, which, while it certainly endorses the Armagh agenda with regard to Patrick and primacy, was probably not written at Armagh but in another Patrician church in the midlands. ${ }^{130}$ Additionally, the role ascribed to St Patrick in the Senchas Már as reviewer of written Irish law is acknowledged in Cáin Fhuithirbe, a legal text written in Munster, in the southwest, between 678 and $683 .{ }^{131}$ This possibly represents acceptance at an early date of Armagh's agenda within an ecclesiastical setting in Munster. On the other hand, there were clearly limits to Armagh's influence. There is only a single, passing reference to Patrick in Adomnán's Life of Columba (c.697), and the fact that Bede, who received most of his information about Irish affairs from Columban circles, appears to have been entirely unaware of Patrick. ${ }^{132}$

125 Ó Muircheartaigh, Gaelic dialects, 147.

126 Whether or not such non-ecclesiastic scholars existed has long been debated among Irish historians. For the most cogent argument in favour of their existence, see Charles-Edwards, Review article: the Corpus Iuris Hibernici.

127 See, for example, Ó Corráin et al., Laws of the Irish; McCone, Pagan Past and Christian Present, 1-28.

128 Charles-Edwards, Early Christian Ireland, 10-67 traces Patrick's travels, as described by Tírechán. Doherty, Cult of St Patrick, 56-66, 75-80, identifies several of the churches in question.

129 For the text, see Additamenta, ed. ad trans. Bieler, 178-9. For commentary, see Charles-Edwards, Early Christian Ireland, 261-262; Byrne, Note on Trim and Sletty; Doherty, Cult of St. Patrick, 75-78.

130 Swift, Tírechán's Motives.

131 Breatnach, Ecclesiastical element. Ó Muircheartaigh, Gaelic dialects, 223-230, identified the Senchas Már as an important vehicle for the spread and acceptance of standard Old Irish also.

132 Adomnán, Vita Columbae, Second Preface, ed. and trans. Anderson and Anderson, 4-5. 
The concept of the Irish nation was not born in Armagh in a way comparable to how the gens Anglorum appears to have been born in Northumbria. Columbanus is the first known individual to self-identify as an Irishman. His concept of what this meant was shaped by his understanding of salvation history as foreshadowed by Scripture, and by contemporary concerns, specifically the orthodoxy of diversity of practice within the unity of the Church. This debate, in Columbanus' time, was shaped by a view, characteristic of the outlook of Gregory the Great, of the Christian Church as comprising numerous snational Churches corresponding to the gentes called to become the new Israel. It is difficult to know how much traction this idea had in Ireland during Columbanus' time and the following decades, but it appears likely that political and ecclesiastical/cultural divisions within Irish society might have mitigated against its rapid acceptance. The defining moment in the early history of the concept appears to have occurred after one of those divisions was healed, namely that over the dating of Easter. Informed by similar ideas to those found in the writings of Columbanus and Gregory, authors working at the behest of Armagh promoted the idea that the Irish nation was united in the past, present and future by its place in salvation history. Having been converted by their national apostle, and awaiting his future judgment, the people of Ireland were to be united on earth as a national Church under the authority of his successors at Armagh. Similar ideas underscored Bede's Historia Ecclesiastica written a generation later, and while no single Irish author had the same impact on the development of Irish identity as Bede had for that of the English, the dossier of Patrician texts produced at the end of the seventh century to support Armagh's claims to primacy might collectively had a similar influence. ${ }^{133}$

\section{Acknowledgements:}

This article is based largely on a paper presented at the conference IIdentity, Ethnicity and Nationhood before Modernity: Old Debates and New Perspectives«, sponsored by The Oxford Research Centre in the Humanities (TORCH), and held in Oxford in April 2015. I am very grateful to the organisers of that conference, and to the Friends of Harvard Celtic Studies, who provided financial support for my attendance. I wish also to thank the reviewers at Medieval Worlds, whose constructive criticisms and suggestions improved this article considerably. For any remaining errors or inadequacies, I alone am responsible.

133 See, additionally, O’Loughlin, Discovering Saint Patrick, 123. 


\section{References}

Additamenta, ed. ad trans. Ludwig Bieler, The Patrician Texts in the Book of Armagh, Scriptores Latini Hiberniae 10 (Dublin, 1979, repr. 2004) 166-179.

Adomnán, Vita Columbae, ed. and trans. Alan Orr Anderson and Marjorie Ogilvie Anderson, Adomnán's Life of Columba, Oxford Medieval Texts (Oxford, 1991).

Anderson, Benedict, Imagined Communities: Reflections on the Origin and Spread of Nationalism (2nd edition) (London, 1991).

The Annals of Ulster (to a.d. 1131), ed. and trans. Seán Mac Airt and Gearóid Mac Niocaill (Dublin, 1983).

Audite Omnes Amantes, ed. Ludwig Bieler, >The Hymn of St. Secundinus`, Proceedings of the Royal Irish Academy 55, section C, 117-127 (repr. in Ludwig Bieler, Ireland and the Culture of Early Medieval Europe, ed. Richard Sharpe (London, 1987) IX).

Auraicept na nÉces, ed. and trans. Anders Ahlqvist, The Early Irish Linguist: an Edition of the Canonical Part of the Auraicept na nÉeces, with Introduction, Commentary and Indices (Helsinki, 1983).

Bannerman, John, Studies in the History of Dalriada (Edinburgh, 1974).

Bede, Historia Ecclesiastica Gentis Anglorum, ed. and trans. Bertram Colgrave and R. A. B. Mynors, Bede's Ecclesiastical History of the English People, Oxford Medieval Texts (Oxford, 1969).

Binchy, Daniel A., The Linguistic and Historical Value of the Irish Law Tracts, in: Dafydd Jenkins (ed.), Celtic Law Papers Introductory to Welsh Medieval Law and Government, Études Présentées à la Commission Internationale pour l'Histoire des Assemblées d'États (Brussels 1973) 73-107 (first published in Proceedings of the British Academy 29 (1943) 195-227).

Binchy, Daniel A. (ed. and trans.), The Saga of Fergus mac Léti, Ériu 16 (1952) 33-48.

Binchy, Daniel A., Linguistic and Legal Archaisms in the Celtic Law-Books, in: Dafydd Jenkins (ed.), Celtic Law Papers Introductory to Welsh Medieval Law and Government, Études Présentées à la Commission Internationale pour l'Histoire des Assemblées d'États (Brussels 1973) 109-120 (originally published in the Transactions of the Philological Society (1959), 14-24).

Binchy, Daniel A., Patrick and his Biographers: Ancient and Modern, Studia Hibernica 2 (1962), 7-173.

Borst, Arno, Der Turmbau von Babel. Geschichte der Meinungen über Ursprung und Viefalt der Sprachen und Völker, 4 vols. in 6 parts (Stuttgart, 1957-1963).

Bracken, Damian, Immortality and Capital Punishment: Patristic Concepts in Irish law, $\mathrm{Pe}$ ritia 9 (1995) 167-186.

Bracken, Damian, Rome and the Isles: Ireland, England and the Rhetoric of Orthodoxy, in: James Graham-Campbell and Michael Ryan (eds.), Anglo-Saxon/Irish Relations before the Vikings, Proceedings of the British Academy 157 (Oxford, 2009) 75-97.

Bracken, Damian, Introduction, in: Tomás Ó Fiaich, Columbanus in His Own Words (Dublin, 2012, first published 1974) 1-9.

Breatnach, Liam, The Ecclesiastical Element in the Old Irish Legal Tract Cáin Fhuithirbe, Peritia 5 (1986) 36-52.

Breatnach, Liam, Varia VI: 3. Ardri as an Old Compound, Ériu 37 (1986) 192-193.

Breatnach, Liam, On Satire and the Poet's Circuit, in Cathal G. Ó Háinle and Donald E. Meek (eds.), Unity in Diversity: Studies in Irish and Scottish Gaelic Language (Dublin, 2004) 25-35. 
Breatnach, Liam, A Companion to the Corpus Iuris Hibernici, Early Irish Law Series 5 (Dublin, 2005).

Breatnach, Liam, The King in the Old Irish Law Text Senchas Már, in Folke Josephson (ed.) Celtic Language, Law and Letters: Proceedings of the Tenth Symposium of the Societas Celtologica Nordica, Meijerbergs Arkiv för Svensk Ordforskning 38 (Göteborg 2010) 107-28.

Breatnach, Liam, The Early Irish Law Text Senchas Már and the Question of its Date, E. C. Quiggin Memorial Lecture (Cambridge 2011).

Brooks, Nicholas, Bede and the English, Jarrow Lecture 1999 (St. Paul's Church, 1999).

Byrne, Francis John, Irish Kings and High-Kings (London, 1973).

Byrne, Francis John, A Note on Trim and Sletty, Peritia 3 (1984) 316-319.

Carey, John, The Irish National Origin-Legend: Synthetic Pseudohistory (with a Memoir of E. C. Quiggin by David N. Dumville), Quiggin Pamphlets on the Sources of Mediaeval Gaelic History 1 (Cambridge, 1994).

Carey, John, An Edition of the Pseudo-Historical Prologue to the Senchas Már, Ériu 45 (1994) 1-32.

Carney, James, Three Old Irish Accentual Poems, Ériu 22 (1971) 28-80.

Carney, James, The Dating of Archaic Irish Verse, in: Stephen Norman Tranter and Hildegard L. C. Tristram (eds.), Early Irish Literature - Media and Communication/Mündlichkeit und Schriftlichkeit in der frühen irischen Literatur (Tübingen, 1989) 39-55.

Charles-Edwards, Thomas M., Review Article: the Corpus Iuris Hibernici, Studia Hibernica 20 (1980) 141-162.

Charles-Edwards, Thomas M., Palladius, Prosper, and Leo the Great: Mission and Primatial Authority, in: David N. Dumville with Lesley Abrams, T. M. Charlese-Edwards, Alicia Corrêa, K. R. Dark, K. L. Maund and A. P. McD. Orchard, Saint Patrick, Studies in Celtic History XIII (Woodbridge, 1993) 1-12.

Charles-Edwards, Thomas M., Language and Society among the Insular Celts, in: Miranda J. Green (ed.), The Celtic World (New York, 1995) 703-736.

Charles-Edwards, Thomas M., The Early Mediaeval Gaelic Lawyer, Quiggin Pamphlets on the Sources of Mediaeval Gaelic History 4 (Cambridge, 1999).

Charles-Edwards, Thomas M., Early Christian Ireland (Cambridge, 2000).

Charles-Edwards, Thomas M., Nations and kingdoms, in Thomas Charles-Edwards (ed.), After Rome, Short Oxford History of the British Isles (Oxford, 2003) 23-60.

Charles-Edwards, Thomas M., The Making of Nations in Britain and Ireland in the Early Middle Ages, in: Ralph Evans (ed.), Lordship and Learning: Studies in Memory of Trevor Aston (Woodbridge, 2004) 11-37.

Charles-Edwards, Thomas M., Early Irish Law, in: Dáibhí Ó Cróinín (ed.), Prehistoric and Early Ireland, New History of Ireland 1 (Oxford, 2005) 331-370.

Charles-Edwards, Thomas M., Perceptions of Pagan and Christian: From Patrick to Gregory the Great, in: Roy Flechner and Máire Ní Mhaonaigh (eds.) with the assistance of Eric Cambridge, The Introduction of Christianity into the Early Medieval Insular World, Converting the Isles I (Turnhout, 2016) 259-278.

Charles-Edwards, Thomas M. and Kelly, Fergus (eds.), Bechbretha, Early Irish Law Series 1 (Dublin, 1983).

Chrysos, Evangelos, The Empire, the gentes and the regna, in: Goetz et al., Regna and Gentes (Leiden/Boston, 2003) 13-19. 
Cogitosus, Vita S. Brigidae, AAAS Feb. 1, § 2, col. 135B; translated by Seán Connolly and Jean-Michel Picard, Cogitosus's Life of St Brigit, Journal of the Royal Society of Antiquaries of Ireland 117 (1987) 5-27.

Collectio canonum Hibernensis, ed. Friedrich Wilhelm August Hermann Wasserschleben, Die irische Kanonensammlung (Giessen, 1974).

Columbanus, Epistulae, ed. and trans. G. S. M. Walker, Sancti Columbani Opera, Scriptores Latini Hiberniae 2 (Dublin, 1970) 2-59.

Comerford, Richard Vincent, Ireland, Inventing the Nation (London, 2003).

Corpus Genealogiarum Hiberniae, ed. Michael A. O’Brien (Dublin, 1962; repr. with an introduction by J. V. Kelleher in 2005).

Corpus Iuris Hibernici, ed. Daniel A. Binchy, 6 vols. (Dublin, 1978).

Cowdrey, H. E. J., Bede and the English People, Journal of Religious History 11 (1981) 501-523.

De Paor, Liam, The Aggrandisement of Armagh, in: T. Desmond Williams (ed.) Historical Studies VIII (Dublin, 1971) 100-110.

Dillon, Miles, A Poem on the Kings of the Eóganachta, Celtica 10 (1973) 9-14.

Doherty, Charles, The Cult of St Patrick and the Politics of Armagh in the Seventh Century, in Jean-Michel Picard (ed.), Ireland and Northern France, A.D. 600-850 (Blackrock, 1991) 53-94.

Dumville, David N., Did Ireland Exist in the Twelfth Century? in: Emer Purcell, Paul MacCotter, Julianne Nyhan and John Sheehan (eds.), Clerics, Kings and Vikings: Essays on Medieval Ireland in Honour of Donnchadh Ó Corráin (Dublin, 2015) 115-126.

Epistolae Merowingici et Karolini Aevi I, ed. Michael Tangl, MGH Epistolae 3 (Berlin, 1892).

Etchingham, Colmán, The Implications of paruchia, Ériu 44 (1993) 139-162.

Etchingham, Colmán, Bishops in the Early Irish Church: a Reassessment, Studia Hibernica 28 (1994) 35-62.

Etchingham, Colmán, Church Organisation in Ireland A.D. 650 to 1000 (Maynooth, 1999).

Etchingham, Colmán, Conversion in Ireland, in: Roy Flechner and Máire Ní Mhaonaigh (eds.), The Introduction of Christianity into the Early Medieval Insular World, Converting the Isles I (Turnhout, 2016) 181-207.

Flanagan, Marie Therese, Strategies of Distinction: Defining Nations in Medieval Ireland, in: Hirokazu Tsurushima (ed.), Nations in Medieval Britain (Donington, 2010) 104-120.

Flechner, Roy, The Hibernensis: a Study, Edition, and Translation with Notes (forthcoming).

Foot, Sarah, The Making of Angelcynn: English Identity before the Conquest, Transactions of the Royal Historical Society, 6th series, 6 (1996) 25-49.

Freeman, Philip, Ireland and the Classical World (Austin, 2001).

Geary, Patrick, Ethnic Identity as a Situational Construct in the Early Middle Ages, Mitteilungen der anthropologischen Gesellschaft in Wien 113 (1983) 15-26 (repr. in Edward Peters (ed.), Folk Life in the Middle Ages, Medieval Perspectives 3/2 (1988) 1-17).

Gildas, De Excidio Brittanniae, ed. and trans. Michael Winterbottom, Gildas: On the Ruin of Britain and Other Works, History from the Sources: Arthurian Period Sources (Chichester, 1978, repr. 2002).

Gillett, Andrew (ed.), On Barbarian Identity: Critical Approaches to Ethnicity in the Early Middle Ages, Studies in the Early Middle Ages 4 (Turnhout, 2002).

Gillett, Andrew, Ethnogenesis: a Contested Model of Early Medieval Europe, History Compass 4/2 (2006) 241-260. 
Goetz, Hans-Werner, Jarnut, Jörg and Pohl, Walter (eds.), Regna and Gentes: the Relationship between Late Antique and Early Medieval Peoples and Kingdoms in the Transformation of the Roman World (Leiden/Boston, 2003).

Hastings, Adrian, The Construction of Nationhood: Ethnicity, Religion and Nationalism, The Wiles Lectures 1996 (Cambridge, 1997).

Heydemann, Gerda, Biblical Israel and the Christian gentes: Social Metaphors and the Language of Identity in Cassiodorus's Expositio psalmorum, in: Walter Pohl and Gerda Heydemann (eds.), Strategies of Identification: Ethnicity and Religion in Early Medieval Europe (Turnhout, 2013) 143-208.

Heydemann, Gerda, People(s) of God? Biblical Exegesis and the Language of Community in Late Antique and Early Medieval Europe, in: Eirik Hovden, Christina Lutter and Walter Pohl (eds.), Meanings of Community across Medieval Eurasia: Comparative Approaches (Leiden, 2016) 27-60.

Holmberg, Matthew Dewey, Towards a Relative Chronology of the Milesian Genealogical Scheme. Unpublished $\mathrm{PhD}$. thesis (Harvard University, 2017).

Isidore, Etymologiae, ed Wallace M. Lindsay, Isidori Hispalensis Episcopi Etymologiae sive Originum Libri XX, 2 vols. (Oxford, 1911; repr. 1987).

John, Eric, The Point of Woden, Anglo-Saxon Studies in Archaeology and History 5 (1992) 127134 .

Johnston, Elva, Literacy and Identity in Early Medieval Ireland (Woodbridge, 2013).

Johnston, Elva, Ireland in Late Antiquity: a Forgotten Frontier? Studies in Late Antiquity 1/2 (2017) 107-123.

Jones, Miriam Adan, A chosen missionary people? Willibrord, Boniface, and the Election of the Angli, Medieval Worlds 3 (2016) 98-115.

Kelly, Fergus, A Guide to Early Irish Law, Early Irish Law Series 3 (Dublin, 1988).

Koch, John T. and Carey, John (eds.), The Celtic Heroic Age: Literary Sources for Ancient Celtic Europe and Early Ireland and Wales, Celtic Studies Publications 1 (2nd edition) (Malden, MA, 1995).

Leabhar Breathnach annso sis: the Irish version of the Historia Britonum of Nennius, ed. and trans. James Henthorn Todd (Dublin 1848).

Lebor Gabála Érenn: the Book of the Taking of Ireland, ed. and trans. R. A. Stewart Macalister, Irish Texts Society vols. 34, 35, 39, 41, 44 (5 vols., Dublin, 1938-1956).

Liber Angeli, ed. and trans. Ludwig Bieler, The Patrician Texts in the Book of Armagh, Scriptores Latini Hiberniae 10 (Dublin, 1979, repr. 2004) 184-191.

Liebermann, Felix (ed. and trans.), Die Gesetze der Angelsachsen 3 vols (Halle, 1903-1916).

Máel Muru Othna, Can a mbunadas na nGaedel, ed. R. I. Best and M. A. O'Brien, The Book of Leinster, formerly Lebar na Nuachongbála, 6 vols., ed. Richard Irvine Best, Osborn Bergin, M. A. O’Brien and Anne O'Sullivan (Dublin, 1954-83) 516-523.

Mac Cana, Proinsias, Mongán mac Fiachna and Immram Brain, Ériu 23 (1972) 102-112.

Mac Cana, Proinsias, The Cult of the Sacred Centre: Essays on Celtic Ideology (Dublin, 2011).

MacNeill, Eoin, Ancient Irish Law: the Law of Status or Franchise, Proceedings of the Royal Irish Academy 36C (1923) 265-316.

MacNeill, Eoin, Early Irish Laws and Institutions (Dublin, 1935).

Markus, R. A., Gregory the Great's Europe, Transactions of the Royal Historical Society 31 (1981) 21-36.

Markus, R. A., Gregor the Great and his World (Cambridge, 1997, repr. 1999). 
McCone, Kim, Pagan Past and Christian Present in Early Irish Literature (Maynooth, 1990, repr. 2000).

McLeod, Neil, Fergus mac Léti and the Law, Ériu 61 (2011) 1-28.

Meyvaert, Paul, Diversity within Unity, a Gregorian Theme, Heythrop Journal 4 (1963) 141162 (reprinted in Paul Meyvaert, Benedict, Gregory and Others (London, 1977).

Muirchú, Vita Sancti Patricii Confessoris, ed. and trans. Ludwig Bieler, The Patrician Texts in the Book of Armagh, Scriptores Latini Hiberniae 10 (Dublin, 1979, repr. 2004) 62-123.

Ní Dhonnchadha, Mairín, The Beginnings of Irish Vernacular Literary Tradition, in: L'irlanda e gli irlandesi nell-alto medioevo, Atti delle Settimane 57 (Spoleto, 2010) 533-596.

Noble, Thomas F. X. (ed.), From Roman Provinces to Medieval Kingdoms, Rewriting Histories (Abingdon, 2006).

Ó Corráin, Donnchadh, Ireland before the Normans, The Gill History of Ireland 2 (Dublin, 1972).

Ó Corráin, Donnchadh, Nationality and Kingship in Pre-Norman Ireland, in: Theodore William Moody (ed.), Historical Studies XI: Nationality and the Pursuit of National Independence (Belfast, 1978) 1-35.

Ó Corráin, Donnchadh, Irish Origin Legends and Genealogy: Recurrent Aetiologies, in: Tore Nyberg, Iørn Piø, P. M. Sørensen and A. Trommer (eds.), History and Heroic Tale: a Symposium, Proceedings of the Eighth International Symposium Organized by the Centre for the Study of Vernacular Literature in the Middle Ages, held at Odense University on 21-22 November, 1983 (Odense, 1985) 51-96.

Ó Corráin, Donnchadh, Creating the Past: the Early Irish Genealogical Tradition (Carroll lecture 1992), Peritia 12 (1998) 177-208.

Ó Corráin, Donnchadh, Breatnach, Liam and Breen, Aidan, The Laws of the Irish, Peritia 3 (1984) 382-438.

Ó Cróinín, Dáibhí, Early Medieval Ireland 400-1200 (Harlow, 1995).

O Cróinín, Dáibhí, Ireland, 400-80o, in: Dáibhí Ó Cróinín (ed.), Prehistoric and Early Ireland, New History of Ireland 1 (Oxford, 2005) 182-234.

Ó Cróinín, Dáibhí (ed.), Prehistoric and Early Ireland, New History of Ireland 1 (Oxford, 2005).

O'Loughlin, Thomas, Muirchú's Theology of Conversion in his Vita Patricii, in: Mark Atherton (ed.), Celts and Christians: New Approaches to the Religious Traditions of Britain and Ireland, Religion, Culture and Society (Cardiff, 2002) 124-145.

O’Loughlin, Thomas, Discovering Saint Patrick (London, 2005).

Ó Muircheartaigh, Peadar, Gaelic Dialects Present and Past: a Study of Modern and Medieval Dialect Relationships in the Gaelic Languages. Unpublished PhD thesis (University of Edinburgh, 2015).

Ó Néill, Pádraig P., Biblical Study and Mediaeval Gaelic History, Quiggin Pamphlets on the Sources of Mediaeval Gaelic History 6 (Cambridge, 2003).

Orchard, Andy, Audite omnes amantes: a Poem in Patrick's Praise, in: David N. Dumville with Lesley Abrams, Thomas M. Charlese-Edwards, Alicia Corrêa, Ken R. Dark, Kari L. Maund and Andrew Philip McDowell Orchard, Saint Patrick, Studies in Celtic History XIII (Woodbridge, 1993) 153-173.

Patrick, Confessio, ed. Ludwig Bieler, Libri Epistolarum Sancti Patricii Episcopi, 2 vols. Royal Irish Academy Dictionary of Medieval Latin from Celtic Sources Ancillary Publications IV (Dublin, 1993; first published Copenhagen, 1951) I:56-91. 
Patrick, Epistola ad Milites Corotici, ed. Ludwig Bieler, Libri Epistolarum Sancti Patricii Episco$p i, 2$ vols. Royal Irish Academy Dictionary of Medieval Latin from Celtic Sources Ancillary Publications IV (Dublin, 1993; first published Copenhagen, 1951) I:91-102.

Picard, Jean-Michel, Vir apostolicus: St Peter and the Claim of Apostolicity in Early Medieval Ireland, in: Pádraic Moran and Immo Warntjes (eds.), Early Medieval Ireland and Europe: Chronology, Contacts, Scholarship: Festschrift for Dáibhí Ó Cróinín, Studia Traditionis Theologiae 14 (Turnhout, 2015), 425-440.

Pohl, Walter, Telling the Difference: Signs of Ethnic Identity, in: Walter Pohl and Helmut Reimitz (eds.), Strategies of Distinction: the Construction of Ethnic Communities 300-800, The Transformation of the Roman World 2 (Boston, 1998) 17-69.

Pohl, Walter, Introduction: Ethnicity, Religion and Empire, in: Walter Pohl, Clemens Gantner and Richard Payne (eds), Visions of Community in the Post-Roman World: the West, Byzantium and the Islamic World, 300-1100 (Farnham, UK, and Burlington, VT, 2012) 1-23.

Prosper of Aquitaine, Epitoma Chronicon, ed. Theodor Mommsen, Chronica Minora I, MGH AA ix (Berlin, 1892) 341-485.

Prosper of Aquitaine, Liber Contra Collatorem, ed. Jaques-Paul Migne, Patrologia Latina 51 (Paris, 1861) col. 213-276.

Regino of Prüm, Epistula ad Hothonem Archiepiscopum Missa, ed. Friedrich Kurze, Reginonis Abbatis Prumiensis Chronicon cum Continuatione Treverensi, MGH SS Rer. Germ. 50 (Hanover, 1890) XIX-XX.

Reynolds, Susan, Medieval origines gentium and the Community of the Realm, History 68/224 (1983) 375-390.

Reynolds, Susan, Kingdoms and Communities in Western Europe 90o-130o (Oxford, 1992; first published, 1984).

Reynolds, Susan, The Idea of the Nation as a Political Community, in: Len Scales and Oliver Zimmer (eds.), Power and the Nation in European History (Cambridge, 2005) 54-66.

Richter, Michael, Bede's Angli: Angles or English?, Peritia 3 (1984) 99-114.

Russell, Paul, ,What was Bests of Every Languages: the Early History of the Irish Language, in: Dáibhí Ó Cróinín (ed.), Prehistoric and Early Ireland, New History of Ireland 1 (Oxford, 2005) 405-450.

Sharpe, Richard, St Patrick and the See of Armagh, Cambridge Medieval Celtic Studies 4 (1982) 33-59.

Smith, Anthony D., Chosen Peoples: Sacred Sources of National Identity (Oxford, 2003).

Stacey, Robin Chapman, Dark Speech: the Performance of Law in Early Medieval Ireland (Philadelphia, 2007).

Swift, Catherine, Tírechán's Motives in Compiling the "Collectanea«: an alternative interpretation, Ériu 45 (1994) 53-82.

Thurneysen, Rudolf, Zur irischen Kanonensammlung, Zeitschrift für celtische Philologie 6 (1908) 1-5.

Thurneysen, Rudolf, Aus dem irischen Recht IV, Zeitschrift für celtische Philologie 16 (1926) 167-230.

Thurneysen, Rudolf, Celtic law, in: Dafydd Jenkins (ed.), Celtic Law Papers Introductory to Welsh Medieval Law and Government, Études Présentées à la Commission Internationale pour l'Histoire des Assemblées d'États (Brussels 1973) 51-70 (first published as Das keltische Recht, Zeitschrift der Savigny-Stiftung für Rechtsgeschichte 55 (1935) 81-104).

Thurneysen, Rudolf, A Grammar of Old Irish (Dublin, 1946). 
Tírechán, Collectanea, ed. and trans. Ludwig Bieler, The Patrician Texts in the Book of Armagh, Scriptores Latini Hiberniae 10 (Dublin, 1979).

Vita S. Gregorii, ed. and trans. Bertram Colgrave, The Earliest Life of Gregory the Great (Lawrence, 1968).

Wadden, Patrick, The First English Invasion: Irish Responses to the Northumbrian Attack on Brega, 684, Ríocht na Midhe 21 (2010) 1-33.

Wadden, Patrick, The pseudo-historical origins of the Senchas Már and royal legislation in early Ireland, Peritia 27 (2016) 141-157.

Wagner, H., The archaic Dind Ríg Poem and Related Problems, Ériu 28 (1977) 1-16.

Warntjes, Immo, Victorius vs Dionysius: the Irish Easter Controversy of 689, in: Pádraic Moran and Immo Warntjes (eds.), Early Medieval Ireland and Europe: Chronology, Contacts, Scholarship: a Festschrift for Dáibhí Ó Cróinín (Turnhout, 2015) 33-99.

Warntjes, Immo and Ó Cróinín, Dáibhí (eds.), The Easter Controversy of Late Antiquity and the Early Middle Ages (Turnhout, 2011).

Wolfram, Herwig, Geschichte der Goten. Von der Anfängen bis zur Mitte des sechsten Jahrhunderts: Entwurf einer historischen Ethnographie (Munich, 1979).

Wormald, Patrick, Lex scripta and verbum Regis: Legislation and Germanic Kingship from Euric to Cnut, in: Peter H. Sawyer, and Ian N. Wood (eds.), Early Medieval Kingship (Leeds, 1977) 105-38 (repr. in Patrick Wormald, Legal Culture in the Early Medieval West: Law as Text, Image and Experience (London, 1999).

Wormald, Patrick, Bede, The bretwaldas and the Origins of the gens Anglorum, in: Patrick Wormald, with Donald Bollough and Roger Collins, (eds.), Ideal and Reality in Frankish and Anglo-Saxon Society: Studies Presented to J. M. Wallace-Hadrill (Oxford, 1983) 99-129.

Wormald, Patrick, The Venerable Bede and the Church of the English, in: Geoffrey Rowell (ed.), The English Religious Tradition and the Genius of Anglicanism (Oxford, 1992) 13-32.

Wormald, Patrick, The leges barbarorum: Law and Ethnicity in the Post-Roman West, in: Goetz et al. (eds.), Regna and Gentes, 21-53.

Yorke, Barbara, Anglo-Saxon gentes and regna, in: Goetz et al., Regna and Gentes, 381-407. 